\title{
Slow-release and organic fertilizers on early growth of Rangpur lime
}

\author{
Daniel Lucas Magalhães Machado ${ }^{1}$, Cícero Cartaxo de Lucena ${ }^{2}$, Dierlei dos Santos ${ }^{2}$, Dalmo Lopes de Siqueira ${ }^{3}$, \\ Pedro Henrique Monteiro Matarazzo ${ }^{2}$,Tiago Barbosa Struiving ${ }^{1}$
}

\begin{abstract}
Slow-release and organic fertilizers are promising alternatives to conventional fertilizers, as both reduce losses by leaching, volatilization and problems of toxicity and/or salinity to plants. The objective of this work was to evaluate the effect of different rates of the organic fertilizer Humato-Macota ${ }^{\circledR}$ compared with the slow-release fertilizer Osmocote ${ }^{\circledR}$ on the growth and nitrogen content in the dry matter of Rangpur lime. A field experiment was conducted in a factorial completely randomized design with an additional treatment $(4 \times 4+1)$. The first factor consisted of four HumatoMacota $^{\circledR}$ rates $(0,1,2$, and $3 \%)$ applied to the substrate; the second factor consisted of the same Humato-Macota ${ }^{\circledR}$ concentrations, but applied as fortnightly foliar sprays; the additional treatment consisted of application of $5 \mathrm{kgm}^{-3}$ Osmocote $^{\circledR}$ 18-05-09. Means of all growth characteristics (plant height, total dry matter, root/shoot ratio and leaf area) and the potential quantum yield of photosystem II (Fv/Fm) were higher when plants were fertilized with the slowrelease fertilizer. The organic fertilizer applied alone did not meet the $\mathrm{N}$ requirement of Rangpur lime.
\end{abstract}

Key words: Fertilization, organic fertilizer, Citrus limonia L. Osbeck.

\section{RESUMO}

\section{Uso de fertilizante de liberação lenta e orgânico no crescimento inicial de limoeiro 'cravo'}

O uso de fertilizantes de liberação lenta e o de fertilizantes orgânicos são alternativas promissoras, uma vez que reduzem as perdas por lixiviação, volatilização e problemas como toxidez ou salinidade às plantas. Objetivou-se, neste trabalho, avaliar o efeito de diferentes doses de fertilizante orgânico (Humato-Macota ${ }^{\circledR}$ ), comparando seu efeito com o do fertilizante de liberação lenta $\left(\right.$ Osmocote ${ }^{\circledR}$ ), sobre o crescimento vegetativo e o teor de nitrogênio na massa de matéria seca de limoeiro 'Cravo'. Foi adotado o delineamento inteiramente casualizado, em arranjo fatorial, com um tratamento adicional $(4 \times 4+1)$, sendo o primeiro fator composto por quatro concentrações de Humato-Macota ${ }^{\circledR}(0 ; 1$; 2; e 3\%) aplicadas no substrato. Para composição do segundo fator, foram utilizadas as mesmas concentrações de Humato-Macota $^{\circledR}$, porém, via foliar, em pulverizações quinzenais. O tratamento adicional consistiu na aplicação de 5,0 $\mathrm{kg} \mathrm{m}^{-3}$ de Osmocote, ${ }^{\circledR}$ da fórmula 18-05-09. Todas as características de crescimento avaliadas (altura, massa de matéria seca total, razão raiz/parte aérea e área foliar), bem como o rendimento quântico potencial do fotossistema II (Fv/Fm), tiveram valores médios maiores quando as plantas foram adubadas com o fertilizante de liberação lenta. $\mathrm{O}$ fertilizante orgânico aplicado isoladamente não supriu a necessidade de N do limoeiro 'Cravo'.

Palavras-chave: Adubação, fertilizante orgânico, Citrus limonia L. Osbeck.

\footnotetext{
Recebido para publicação em março de 2010 e aprovado em fevereiro de 2011

${ }_{1}^{1}$ Undergraduate students in Agronomy. Universidade Federal de Viçosa, Departamento de Fitotecnia, Av. Peter Henry Rolfs, s/n, 36570-000, Viçosa, Minas Gerais, Brazil. danielm.machado@ ufv.br, struiving@ hotmail.com

2 Agronomist Engineers, Doctor Science students. Universidade Federal de Viçosa, Departamento de Fitotecnia, Av. Peter Henry Rolfs, s/n, 36570-000, Viçosa, Minas Gerais, Brazil. lucenacc@gmail.com, dierlei@vicosa.ufv.br, pedro_matarazzo@yahoo.com.br

$\frac{1}{3}$ Agronomist Engineer, Doctor Science. Universidade Federal de Viçosa, Departamento de Fitotecnia, Av. Peter Henry Rolfs, s/n, 36570-000, Viçosa, Minas Gerais, Brazil. siqueira@ufv.br.
}

Rev. Ceres, Viçosa, v. 58, n.3, p. 359-365, mai/jun, 2011 


\section{INTRODUCTION}

Citrus containerized nursery production is a technology that is still being refined (Pereira \& Carvalho, 2006). The initial vigor of the rootstock is one of the seedling quality factors, as it reduces the time for rootstocks to reach the grafting point (Bernardi et al., 2000).

Moreover, seedling growth in polytubes can be influenced by fertility of substrate, then supplementation with side dressing and/or foliar fertilization is usually required (Decarlos Neto et al. 2002; Scivittaro et al., 2004).

Besides adequate fertilizer rates, split application is important, to avoid nutrient leaching, mainly $\mathrm{N}$ and $\mathrm{K}$, due to continuous irrigation and the small size of containers (Prado et al., 2008).

Studies on the effects of fertilization on growth of citrus rootstocks have shown that nitrogen, required in large amounts and used in key metabolic processes in plants, is a critical element to the process. Because of its high susceptibility to loss, nitrogen should be supplied gradually to plants, in split applications of soluble sources (Decarlos Neto et al., 2002).

A promising and practical alternative is the use of fertilizers that allow a gradual release of the nutrient during the seedling formation or organic fertilizers, based on fulvic and humic acids, to reduce losses by leaching and volatilization and avoid toxicity or salinity to plants (Khalaf \& Koo, 1983; Shaviv, 200 1; Girardi \& Mourão Filho, 2003). Slow-release fertilizers promote a more homogeneous nutrient distribution in the substrate. They also favor the synchronization between nutrient supply and the physiological demand of the plant, as the rate of nutrientrelease is directly proportional to temperature, with optimalvalues close to $21 \circ \mathrm{C}$, when plants are in full metabolic activity (Oertli, 1980; Perin et al., 1999). In addition, these non-conventional fertilizers will reduce the need for additional fertilizations during the period of seedling formation (Compo, 2004).

The main disadvantage is their cost. Slow-release fertilizers are more expensive than soluble fertilizers and require rate adjustment in different production systems to optimize input use and ensure the economic production of rootstocks. Reliable information on rates and application modes for these products is still scarce in the literature, not meeting nursery growers needs (Girardi \& Mourão Filho, 2003).

Furthermore, monitoring of $\mathrm{N}$ nutritional status in citrus rootstocks requires information on non-destructive methods to help the $\mathrm{N}$ diagnosis (Decarlos Neto et al., 2002). Studies have shown that there is a positive correlation between plant growth characteristics and leaf chlorophyll content determined by spectrophotometry or using indirect meters (Shadchina \& Dmitrieva, 1995; Neilsen et al., 1995; Lopez-Cantarero et al. 1994; Minotti et al. 1994). These authors determined chlorophyll content in wheat by the method of Arnon (1949) and found that it can be used as a suitable characteristic for determination of $\mathrm{N}$ absorbed by plants.

Likewise, chlorophyll fluorescence has been used as a diagnostic tool for plant stress, including nutritional stress, with the advantage of being non-destructive and of rapid determination (Pestana et al., 2001).

When plants are exposed to light, under biotic or abiotic stress, decreases in $\mathrm{F}_{\mathrm{v}} / \mathrm{F}_{\mathrm{m}}$ ratio are often observed. Falqueto et al. (2008) found a high correlation between $\mathrm{F}_{\mathrm{v}} / \mathrm{F}_{\mathrm{m}}$ and $\mathrm{N}$ content in rice cultivars.

I he $\mathrm{F} / \mathrm{F}_{\mathrm{m}}$ ratio represents the efficiency of excitation energy capture by open PSII reaction center (P680) and electron transport to plastoquinone $\left(\mathrm{PQH}_{2}\right)$. The maximum level of fluorescence $\left(\mathrm{F}_{\mathrm{m}}\right)$ indicates the full reduction of plastoquinone A (QA), whereas $\mathrm{F}_{\mathrm{v}}$ is the variable fluorescence $\left(=F_{m}-F_{0}\right)$ and indicates the magnitude of the initial fluorescence rise from $\mathrm{F}$ oto $\mathrm{Fm}$. In plants with a healthy photosynthetic apparatus, i.e., without stress, the $\mathrm{F}_{\mathrm{v}} / \mathrm{F}_{\mathrm{m}}$ ratio varies between 0.750 and 0.850 (BolhàrNordenkampf et al., 1989), while a decrease in this ratio reflects the presence of photoinhibitory damage in the PSII reaction centers (Björkman \& Demming, 1987).

Therefore, the aim of this study was to evaluate the initial growth of seedlings of Rangpur lime [Citrus limonia (L.) Osbeck] as affected by substrate fertilization with either slow release fertilizer (Osmocote ${ }_{\circledast}$ ) or organic fertilizer (Humato-Macota ${ }^{\circledR}$ ).

\section{MATERIAL AND METHODS}

A field experiment was carried out at the citrus orchard of the Universidade Federal de Viçosa (UFV), from 21/05 to 21/08 2007. Seed lots of Rangpur lime were obtained from the Citrus Collection of the Setor de Fruticultura - UFV.

The experiment was arranged in a factorial completely randomized design with an additional treatment $(4 \times 4+1)$ and four replicates with 12 seedlings per plot. The factorial design consisted of four concentrations of organic fertilizer (Humato-Macota $₫)(0,1,2$, and $3 \%)$ applied to the substrate at planting, and four concentrations $(0,1,2$, and $3 \%$ ) applied as fortnightly foliar sprays after germination. The additional treatment consisted of application of $5 \mathrm{~kg} \mathrm{~m}_{-3}$ Osmocote ${ }_{\otimes}$ 18-05-09.

Table 1 shows the chemical composition of the organic fertilizer. The additional treatment consisted of application of $5 \mathrm{kgm}-3$ of the slow-release fertilizer Osmocote ${ }^{8}$ 18-0509 to Plantmax substrate (Moisture: 50\%; water holding 
Table 1. Chemical composition of the organic fertilizer Humato-Macota $₫$, isolated from California red worm castings, in $\mathrm{mg} \mathrm{L}_{-1}$

\begin{tabular}{lccccccccccc}
\hline $\begin{array}{l}\text { Humic } \\
\text { acids }\end{array}$ & $\begin{array}{c}\text { Fulvic } \\
\text { acids }\end{array}$ & $\mathbf{C}$ & $\mathbf{N}$ & $\mathbf{P}$ & $\mathbf{K}$ & $\mathbf{C a}$ & $\mathbf{M g}$ & $\mathbf{F e}$ & $\mathbf{C u}$ & $\mathbf{Z n}$ & Mn \\
\hline 178.35 & 143.83 & 3.088 & 294 & 54.27 & 25 & 250.5 & 176.9 & 16.85 & 1.09 & 0.33 & 4.47 \\
\hline
\end{tabular}

capacity: $150 \%$; $\mathrm{pH}: 5.8 \pm 0.5$; electrical conductivity $1.2 \pm$ $0.3 \mathrm{mS} / \mathrm{cm}$ ) at sowing in $0.05 \mathrm{dm}_{3}$ poly tubes.

The organic fertilizer Humato-Macota®, at concentrations described above, was added to $100 \mathrm{~mL}$ of water and applied to the substrate of each plot at the time of sowing. Foliar sprays were carried out at 15, 30, 45, 60 and 75 days after germination.

The experiment was evaluated 90 days after germination. Initially, seedling height was measured and, later, chlorophyll content was measured with a SPAD-502® chlorophyll meter (Minolta, Japan). For this evaluation, we considered the average of four SPAD readings, on the $3_{\mathrm{rd}}, 4_{\mathrm{th}}, 5_{\mathrm{th}}$ and $6 \mathrm{~h}$ leaves from the apex of the plant in each plot.

The physiological status was evaluated using the parameters of chlorophyll $a$ fluorescence $\left(F_{\mathrm{o}}, \mathrm{F}_{\mathrm{v}}, \mathrm{F}_{\mathrm{v}} / \mathrm{F}_{\mathrm{m}}\right)$ measured on the 5 th leaf from the apex, previously adapted to the dark for 30 minutes. One measurement was recorded per plant, using a portable FIM 1500 fluorometer $($ ADC, UK). Finally, the values obtained individually, per plant, were used to calculate an average per plot.

Then, plants were removed from the tubes, and substrate was washed from the roots. After drying, leaves were cut off and the seedlings were separated into aerial parts and root system at the base of the collar. The leaves were brought to the laboratory, where leaf area was determined by the destructive method, using the 2000 Area Meter $\circledast$, expressed in $\mathrm{cm}_{2}$.

After determination of leaf area, leaves and stems were dried in forced-air ovens to constant weight and dry matter was determined in grams $(\mathrm{g})$. The same procedure was done for the roots. The dried material was ground in a Wiley mill to pass a 20-mesh sieve and samples were stored in paper bags. In these samples, total nitrogen content was determined by Kjeldahl method after sulfuric digestion $\left(\mathrm{H}_{2} \mathrm{SO}_{4}\right.$ and $\left.\mathrm{H}_{2} \mathrm{O}_{2}\right)$ of plant tissue (Malavolta et al., 1997), at the Laboratório de Nutrição Mineral de Plantas / UFV.

Data were examined by analysis of variance and regression analysis, a 5\% probability level, using the Sistema de Análises Estatísticas e Genéticas (SAEG) software (UFV, 1997). The selection of the model in the regression analysis was based on the significance of the F test at $5 \%$ probability level, the biological significance and the coefficient of determination. Because there was no significant differences between means of the treatments that comprised the factorial, this group was contrasted with the additional treatment.

\section{RESULTS AND DISCUSSION}

Application of the organic fertilizer to substrate and supplementation via foliar sprays had no significant effect on seedling height, unless the concentrations of fertilizerin the substrate were combined with concentration of $2 \%$ applied as foliar sprays. The highest seedling height (average $10 \mathrm{~cm}$ ) was recorded for the treatment with slow-release fertilizer (Table 2, Figure 1 A). These results agree with reports by Mendonça et al. (2007), who observed higher vigor in passion fruit seedlings treated with slowrelease fertilizer.

Total dry matter of seedlings was not influenced by the application of organic fertilizer, but was higher in plants fertilized with slow-release fertilizer (Table 2). The total dry matter of plants treated with slow-release fertilizer had means close to $0.80 \mathrm{~g}$ contrasting with $0.20 \mathrm{~g}$ in plants treated with organic fertilizer (Figure $1 \mathrm{~B}$ ). The reason for that is the more ready availability of nutrients to plants by the mineral fertilizer (Osmocote ${ }_{\circledast}$ ). The increased availability of nitrogen usually brings positive effects on the rate of carbon assimilation, since this nutrient is one of the main components of the photosynthetic system, and a consequent increase in total dry mass (Taiz \& Zeiger, 2004).

The shoot/root dry matter ratio was 2.40 for the slowrelease fertilizer, whereas for the organic fertilizer, it was higher (1.11), regardless of the concentration and mode of application (Figure $1 \mathrm{C}$ ).

According to Marschner (1995), the nitrogen content may influence the shoot/root ratio. Under low nutrient availability, there is less growth of aerial parts and roots become long and unbranched. At adequate $\mathrm{N}$ levels, development and branching of the root system are normal. Under excess nutrient conditions, there is excessive branching, but the root system is reduced and development of the aerial part is stimulated.

The shoot/root ratio is useful for studying the balance between organs, which is influenced by changes in the environment, since there is interdependence among organs, which can be altered by various factors such as temperature, water balance, nutrients and carbon. Changes in the morphology of the root system and its volume, forexample, can affect the uptake of water and nutrients, especially those with less mobility in the soil and that reach the roots by diffusion. Plants with welldevelopedroot systems usually have better conditions for the establishment in the field (Bernardi et al., 2000).

Rev. Ceres, Viçosa, v. 58, n.3, p. 359-365, mai/jun, 2011 
Table 2. Summary of analysis of variance (Mean square) for plant height (ALT), leaf area (AF), total dry matter (MST), dry matter of aerial part (MSPA), root dry matter (MSR), root/shoot dry matter ratio (MS R/PA), initial fluorescence (Fo), potential quantumyield of photosystem II $\left(\mathrm{F}_{\mathrm{v} / \mathrm{Fm})}\right.$ and chlorophyll content (SPAD) of Rangpur lime seedlings fertilized with organic fertilizer and slow-release fertilizer

\begin{tabular}{|c|c|c|c|c|c|c|c|c|c|}
\hline FV & $\begin{array}{l}\text { ALT } \\
\text { (cm) }\end{array}$ & $\begin{array}{l}\mathrm{AF} \\
\left(\mathrm{cm}^{2}\right)\end{array}$ & $\begin{array}{l}\text { MST } \\
\text { (g) }\end{array}$ & $\begin{array}{c}\text { MSPA } \\
\text { (g) }\end{array}$ & $\begin{array}{c}\text { MS R MS } \\
\text { (g) }\end{array}$ & $\begin{array}{r}\text { R/PA } \\
\text { (g) }\end{array}$ & $\mathbf{F}_{\mathbf{0}}$ & $\mathbf{F} / \mathbf{F}_{\mathrm{m}}$ & SPAD \\
\hline Substrate & $0.486^{* *}$ & $2.622^{\mathrm{ns}}$ & $0.001^{\mathrm{ns}}$ & $0.0006^{\mathrm{ns}}$ & $0.0002^{\mathrm{ns}}$ & $0.008^{\mathrm{ns}}$ & $1165.05^{\mathrm{ns}}$ & $0.0095^{\mathrm{ns}}$ & $3.11_{\mathrm{ns}}$ \\
\hline Foliar & $0.165^{\mathrm{ns}}$ & $1.871^{\mathrm{ns}}$ & $0.001^{\mathrm{ns}}$ & $0.0005^{\mathrm{ns}}$ & $0.0003^{\mathrm{ns}}$ & $0.006^{\mathrm{ns}}$ & \multicolumn{2}{|c|}{$594.01^{\mathrm{n} . \mathrm{s}} 0.0028^{\mathrm{n} . \mathrm{s}}$} & $14.03^{\text {n.s }}$ \\
\hline Interaction & $0.393 * *$ & $1.003^{\mathrm{ns}}$ & $0.000^{\mathrm{ns}}$ & $0.0002^{\mathrm{ns}}$ & $0.0001^{\mathrm{ns}}$ & $0.015^{\mathrm{ns}}$ & $2808.35^{\mathrm{ns}}$ & $0.0037^{\mathrm{ns}}$ & $11.09^{\text {n.s }}$ \\
\hline $\mathrm{CV} \%$ & 6.96 & 19.67 & 14.22 & 16.71 & 13.56 & 14.7 & 22.98 & 8.7 & 14.15 \\
\hline Contrast & $5.49 * *$ & $21.49 * *$ & $0.54 * *$ & $0.42 * *$ & $0.12 * *$ & $-0.48 * *$ & $52.08^{\mathrm{ns}}$ & $0.05^{\mathrm{ns}}$ & $33.52 * *$ \\
\hline DMS & 1.24 & 4.75 & 0.1 & 0.06 & 0.04 & 0.41 & 265.84 & 0.17 & 10.25 \\
\hline
\end{tabular}

** significant at $1 \%$ probability level. $\mathrm{n} . \mathrm{s}=$ non significant
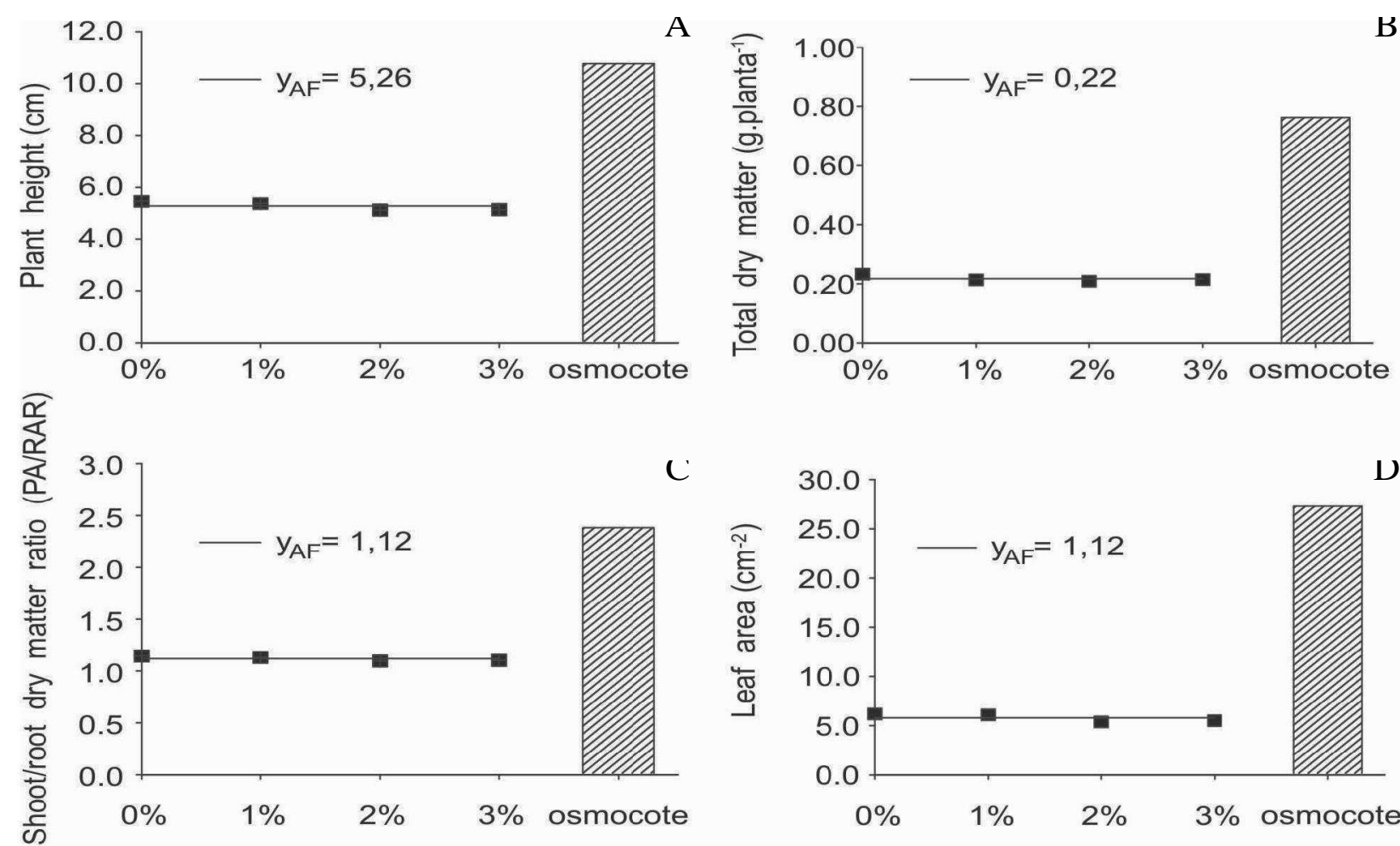

C

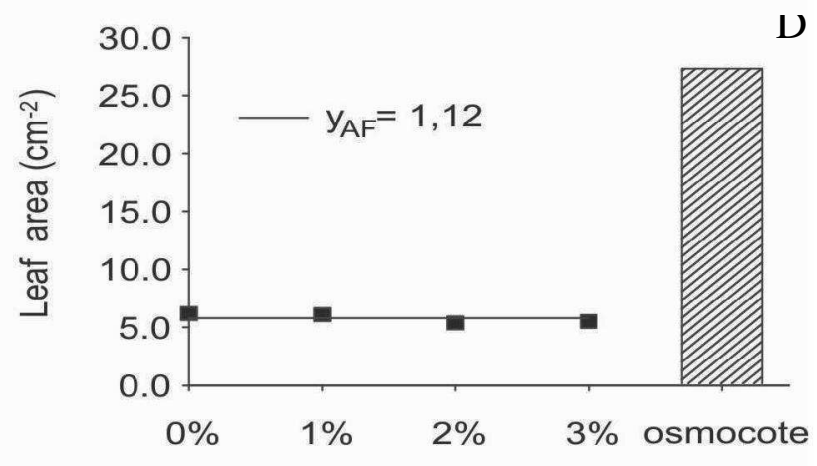

Figure 1. Plant height (A), total dry matter (B), root/shoot dry matter ratio (C), and leaf area (D) of Rangpur seedlings fertilized with the slow-release fertilizer Osmocote ${ }^{\circledR}$ (to the substrate) and the organic fertilizer Humato-Macota® (to the substrate and foliar supplementation).

Another factor to be considered is that in citrus, growth of roots and aerial parts occurs through alternating cycles. Bevington \& Castle (1985) determined that, in young plants, even when temperature and soil moisture are not limiting factors, root growth is cyclical, alternating with the growth of the aerial part.

Leaf area was not affected by the use of the organic fertilizer, corresponding only to $22 \%$ of the treatment with Osmocote $\AA$ (Figure 1D). Leaf area is an important characteristic, because leaves are instrumental in capturing light energy and use it to convert the carbon atoms of $\mathrm{CO}_{2}$ into organic carbon through photosynthesis.
The SPAD readings were also not significantly different among the treatments with the organic fertilizer, with means approximately $50 \%$ lower than those found for plants treated with the slow-release fertilizer. The lower SPAD readings in the treatments with the organic fertilizer, in comparison with the slow-release fertilizer (Figure 2A), indicate low nitrogen content in its composition.

Malavolta et al. (1997) reported that the leaf chlorophyll content indicates the level of plant nutrition, relative to $\mathrm{N}$, and is not affected by its luxury consumption, because the plant does not produce chlorophyll more than 
it needs. Decarlos Neto et al. (2002) found that levels of leaf chlorophyll content in the citrus rootstocks TangeloOrlando, Rangpur, Volkamer, Cleopatra and Sunki had significant positive correlations with height, stem diameter, leaf area, dry matter of aerial parts and roots, and $\mathrm{NO}_{3}-\mathrm{N}$ content in the aerial part.

Vale \& Prado (2009) showed that SPAD readings provide fast and non-destructive estimates of chlorophyll content in leaves. These values correlated with nitrogen content and can be used as a diagnosis for the nutritional status of this nutrient in the plant. This is because between 50 and $70 \%$ of total $\mathrm{N}$ in leaf are associated with enzymes in chloroplasts.

The results obtained with the SPAD index correlated with the visual nitrogen deficiency symptoms (data not shown) in the treatments with organic fertilizer, regardless of the applied rates. There were no such symptoms in the treatments with the slow-release fertilizer. Because nitrogen is required in high quantities and influence major metabolic processes, the deficiency in these plants may be associated with low nitrogen content in the composition of the organic fertilizer. Vale et al. (2009) found that 1840 $\mathrm{mg} \mathrm{dm}-3$ of nitrogen increased the content and accumulation of the nutrient in the dry matter, which was a higher value than that found in the composition of the organic fertilizer (Table 1). Similar to the chlorophyll content, the photochemical quenching determined by the potential quantum yield of photosystem II $\left(\mathrm{F}_{\mathrm{v}} / \mathrm{F}_{\mathrm{m}}\right)$ was lower in plants fertilized with the organic fertilizer (approximately 0.650), while plants fertilized with the slow-release fertilizer had a higher quantum yield (approximately0.700) (Figure 2C).

We did not find in the literature searched any study on the use of this organic fertilizer. The contrast of the organic fertilizer treatment groups with the additional treatment, the slow-release fertilizer, was significant for all characteristics. The efficiency of slow-release fertilizers in citrus has been reported in other studies (Jackson \& Davies, 1984; Obreza, 1990; Zekri \& Koo, 1992).

Total nitrogen levels in plants fertilized with the slowrelease fertilizer (Osmocote ${ }_{\circledast}$ ) were higher than in plants fertilized with the organic fertilizer (Humato-Macota $₫$ ) (Figure 3), confirming the SPAD readings. Serrano et al. (2004) also reported increase in leaf $\mathrm{N}$ contents of Rangpur rootstocks with the incorporation of slow-release fertilizer. In the same way, Decarlos Neto (2000) evaluated the response of citrus rootstocks to different levels of nitrogen applied to the substrate and found mean total-N content similar to our study.

Increasing concentrations (from 0 to $3 \%$ ) of organic fertilizer applied to the substrate, in combination with foliar supplementation, reduced total nitrogen (Figure 3).

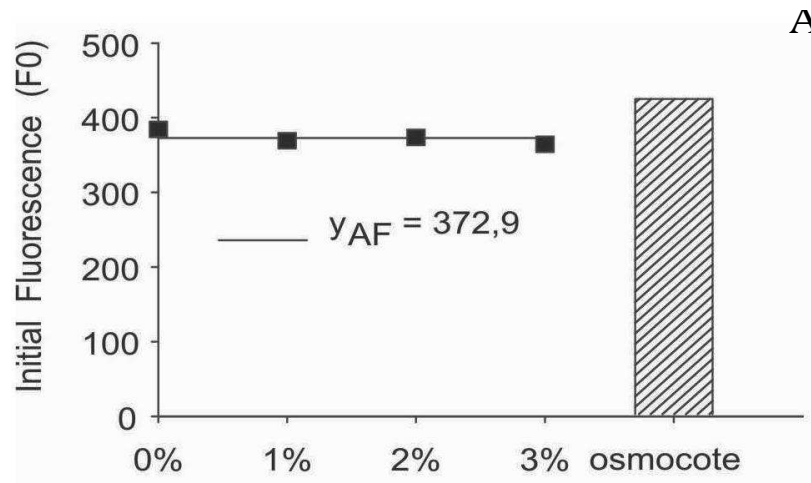

A

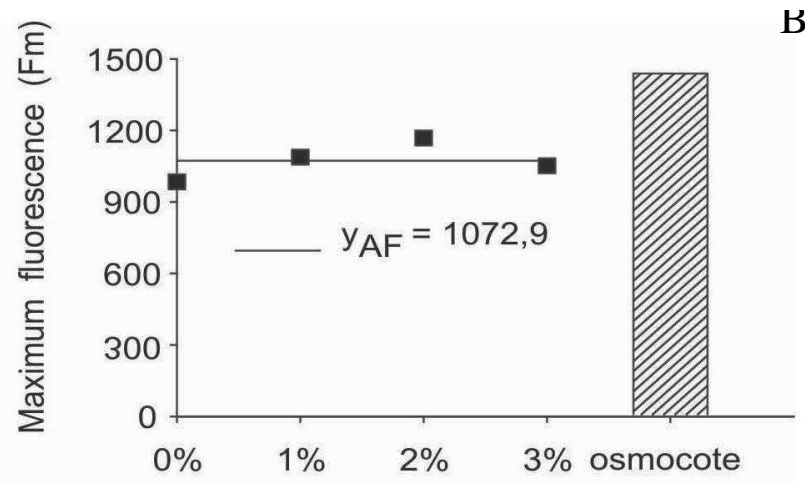

C

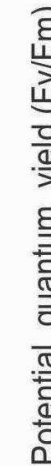

B

U

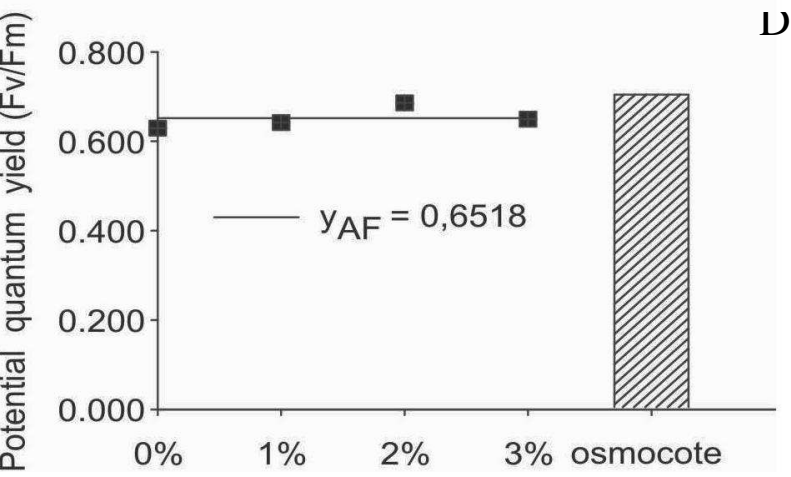

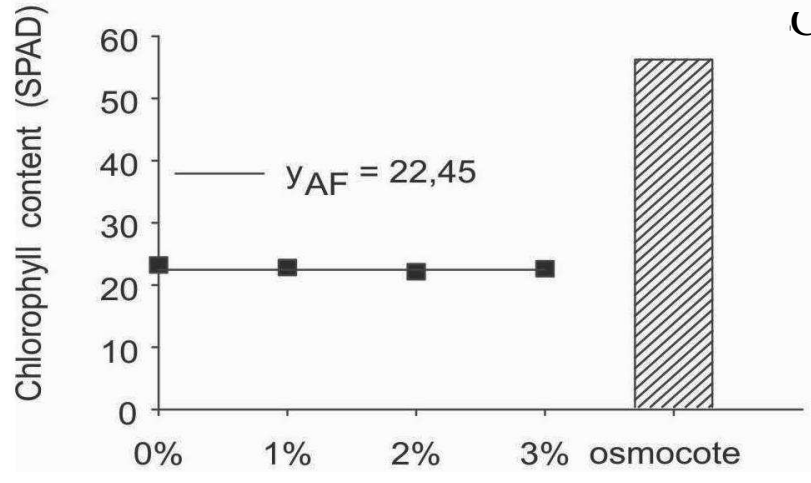

Figure 2. Initial fluorescence $\left(\mathrm{F}_{\mathrm{o}}\right)(\mathrm{A})$, maximum fluorescence $\left(\mathrm{F}_{\mathrm{m}}\right)(\mathrm{B})$, chlorophyll content $(\mathrm{SPAD})(\mathrm{C})$, and potential quantum yield $\left(\mathrm{F}_{\mathrm{v}} / \mathrm{F}_{\mathrm{m}}\right)(\mathrm{D})$ of Rangpur seedlings fertilized with the slow-release fertilizer Osmocote ${ }^{\circledR}$ (to the substrate) and the organic fertilizer Humato-Macota ${ }^{\circledR}$ (to the substrate and foliar supplementation). 


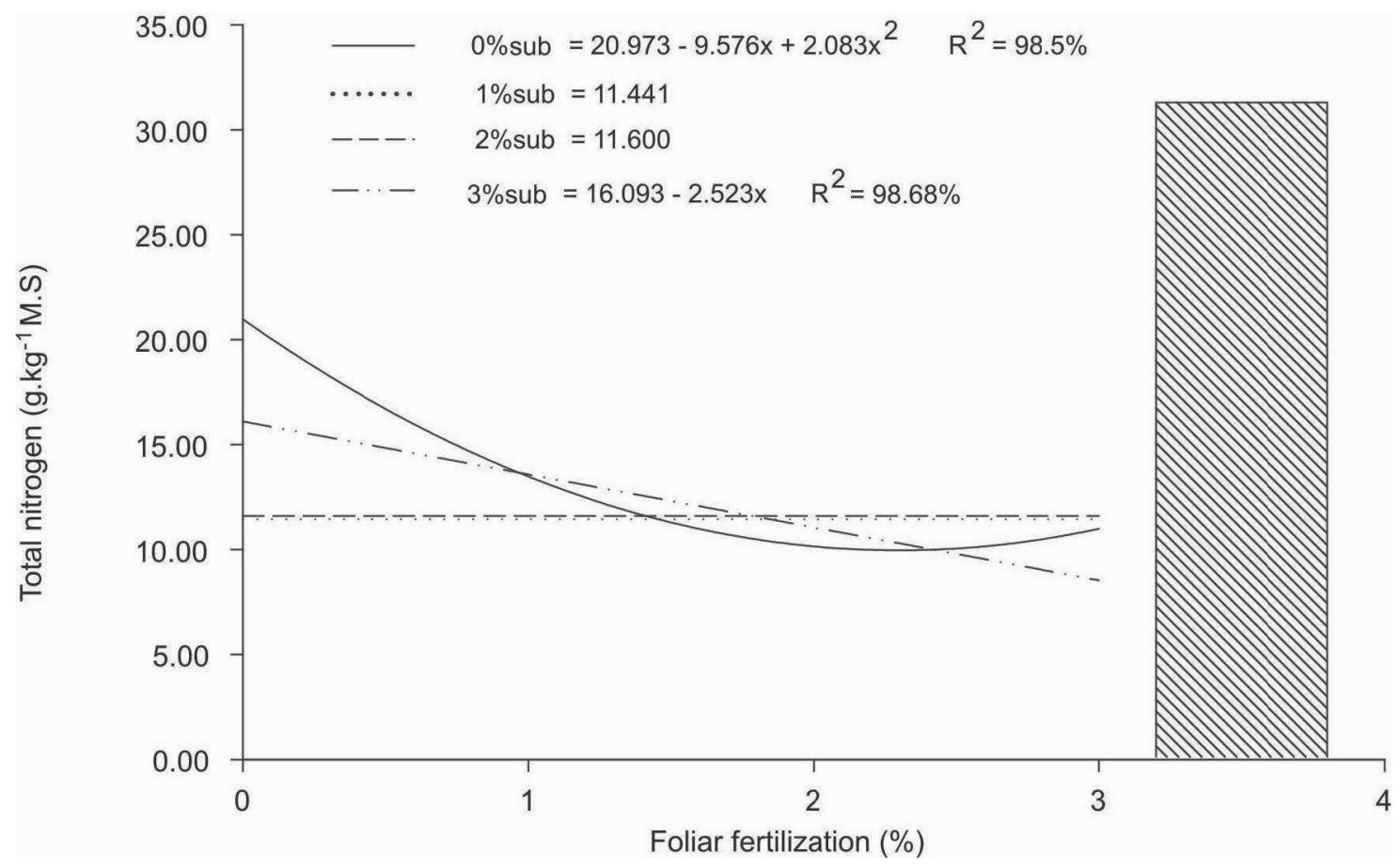

Figure 3. Total nitrogen content (g.kg-1 MS) in Rangpur seedlings fertilized with the slow-release fertilizer Osmocote ${ }^{\circledR}$ (to the

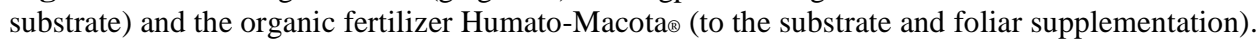

\section{CONCLUSIONS}

The organic fertilizer alone did not supply adequate nitrogen to Rangpur lime plants.

For all characteristics studied, the best vigor indices of Rangpur lime seedlings were obtained with slow-release fertilizer.

\section{REFERENCES}

Arnon DI (1949) Copper enzymes in isolated chloroplasts: polyphenoloxydase in Beta vulgaris. Plant Physiology, 24:115 .

Bernardi ACC, Carmello QAC \& Carvalho AS (2000) Desenvolvimento de mudas de citros cultivadas em vaso em resposta à adubação NPK. Scientia Agricola, 57:733-738.

Bevington KB \& Castle WS (1985) Annual root growth pattern of young citrus trees in relation to shoot growth, soil temperature, and soil water content. Journal American Society for Horticultural Science, 110:840-845.

Björkman O \& Demming B (1987) Photon yield of $\mathrm{O}_{2}$ evolution and chlorophyll fluorescence characteristics at $77 \mathrm{k}$ among vascular plants of diverse origins. Planta, 170:61-66.

Bolhàr-Nordenkampf HR, Long SP \& Baker NR (1989) Chlorophyll fluorescence as probe of the photosynthetic competence of leaves in the field a review of current instrument. Functional Ecology, 3:497-514.

Compo (2004) Fertilizante de liberação lenta. Disponível em: <www.compo.com.br>. Acessado em: 26 de maio de 2011.

Decarlos Neto A, Siqueira DL, Pereira PRG \& Alvarez VVH (2002) Crescimento de porta-enxertos de citros em tubetes influenciados por doses de N. Revista Brasileira de Fruticultura, 24:199. 203.
Decarlos Neto A (2000) Adubação e nutrição nitrogenada de portaenxertos de citros produzidos em tubetes. Dissertação de Mestrado. Universidade Federal de Viçosa, Viçosa, 131p.

Falqueto A, Cassol D, Magalhães Júnior A, Oliveira A \& Bacarin M (2008) Características da fluorescência da clorofila em cultivares de arroz com ciclo precoce, médio e tardio. Revista Brasileira de Biociências, 5:579-581.

Girardi EA \& Mourão Filho FAA (2003) Emprego de fertilizantes de liberação lenta na formação de pomares de citros. Revista Laranja, 24:507-518.

Jackson LK \& Davies FS (1984) Mulches and slow-release fertilizers in a citrus young tree care program. Proceedings of the Florida State Horticultural Society, 97:37-39.

Lopez-Cantarero I, Lorente FA \& Romero L (1994) Chlorophylls are good indicators of nitrogen and phosphorus levels. Journal of Plant Nutrition, 17:979-990.

Khalaf HA \& Koo RCJ (1983) The use of controlled release nitrogen on container grown citrus seedlings. Citrus \& Vegetable Magazine, 46:10.

Malavolta E, Vitti GC \& Oliveira SA (1997) Avaliação do estado nutricional das plantas: princípios e aplicações. $2^{\mathrm{a}} \mathrm{ed}$. Piracicaba, POTAFOS. 319p.

Marschner H (1995) Mineral nutrition of higher plants. San Diego, Academic Press. 889p.

Mendonça V, Ferreira EA, Paula YCM, Batista TMV \& Ramos JD (2007) Crescimento de mudas de maracujazeiro-amarelo influenciado por doses de nitrogênio e de superfosfato simples. Revista Caatinga, 20:137-143.

Minotti PL, Halseth DE \& Sieczka JB (1994) Field chlorophyll measurements to assess the nitrogen status of potato varieties. HortScience, 29:1497-1500.

Neilsen D, Hogue EJ, Neiilsen GH \& Parchomchuk P (1995) Using SPAD-502 values to assess the nitrogen status of apple trees. HortScience, 30:508-512.

Rev. Ceres, Viçosa, v. 58, n.3, p. 359-365, mai/jun, 2011 
Obreza TA (1990) Young 'Hamlin' orange tree fertilizer response in south crust Florida. Proceedings of the Florida State Horticultural Society, 103:12-16.

Oertli JJ (1980) Controlled-release fertilizers. Fertilizer Research, $1: 103-123$.

Pereira BFF \& Carvalho AS (2006) Métodos de forçamento de borbulhas e aplicação de cianamida hidrogenada para produção de mudas de laranja 'valência' sobre citrumelo 'swingle' em viveiro telado. Revista Brasileira de Fruticultura, 28:151-153.

Perin JR, Carvalho AS, Mattos Junior D \& Cantarella H (1999) Efeitos de substratos e doses de fertilizante de liberação lenta no teor de clorofila e desenvolvimento vegetativo do limoeiro 'Cravo' em tubetes. Revista Laranja, 20:457-462.

Pestana M, David M, De-Varennes A, Abadia J \& Faria EA (2001) Responses of "Newhall" orange trees to iron deficiency in hydroponics: effects on leaf chlorophyll, photosynthetic efficiency, and root ferric chelate reductase activity. Journal of Plant Nutrition, 24:1609-1620.

Prado RM, Rozane DE, Camarotti GS, Correia MAR, Natale W Barbosa JC \& Beutler AN (2008) Nitrogênio, fósforo e potássio na nutrição e na produção de mudas de laranjeira 'Valência', enxertada sobre citrumeleiro 'Swingle'. Revista Brasileira de Fruticultura, 30:812-817

SAEG (2007) Sistema para análises estatísticas, versão 9.1. Viçosa, UFV.
Scivittaro WB, Oliveira RP, Morales CFG \& Radmann EB (2004) Adubação nitrogenada na formação de porta-enxertos de limoeiro 'Cravo' em tubetes. Revista Brasileira de Fruticultura, 26:131-135

Serrano LAL, Marinho CS, Carvalho AJC \& Monnerat PH (2004) Efeitos de sistemas de produção e doses de adubo de liberação lenta no estado nutricional de portaenxerto cítrico. Revista Brasileira de Fruticultura, 26:524-528.

Shadchina TM \& Dmitrieva VV (1995) Leaf chlorophyll content as a possible diagnostic mean for the evaluation of plant nitrogen uptake from the soil. Journal of Plant Nutrition, 18:1427-1437.

Shaviv A (2001) Advances in controlled-release fertilizers. Advances in Agronomy, 71:1-49.

Taiz L \& Zeiger E (2004) Fisiologia vegetal. $3^{\mathrm{a}}$ ed. Porto Alegre, Artmed. 719p.

Vale DW \& Prado RM (2009) Adubação NPK e o estado nutricional de 'Citrumelo' por medida indireta da clorofila. Revista Ciência Agronômica, 40:266-271.

Vale DW, Prado RM, Sousa WA \& Martins ABG (2009) Doses de nitrogênio fósforo e potássio na nutrição do portaenxerto cítrico de limoeiro Cravo. Scientia Agraria, 10:61-66.

Zekri M \& Koo RCJ (1992) Use of controlled-release fertilizers for young citrus trees. Scientia Horticulturae, 49:233-241. 